\title{
Krzysztof Surówka
}

Cracow University of Economics

e-mail: krzysztof.surowka@uek.krakow.pl

ORCID: 0000-0001-8900-8970

THE INFLUENCE OF REVENUE SOURCES

ON THE FINANCIAL INDEPENDENCE

AND INVESTMENT ACTIVITY OF COMMUNES

AND CITIES WITH 'POWIAT' RIGHTS IN POLAND

WPLYW ŹRÓDEL DOCHODÓW

NA SAMODZIELNOŚĆ FINANSOWĄ

I DZIALALNOŚĆ INWESTYCYJNĄ GMIN I MIAST

NA PRAWACH POWIATU W POLSCE

DOI: $10.15611 / \mathrm{pn} .2019 .7 .12$

JEL Classification: H7

Summary: Local government is a part of the public finance sector, therefore a significant part of its income has a strictly defined purpose. Such focusing of income on the financing of specific tasks limits the scope of the financial autonomy of local government and reduces it to the role of administering public funds and spending them on financing particular tasks. Supervision and control over local government are also a limitation of financial independence of local government units (LGUs) - municipalities, districts and voivodeships. At the same time, however, the essence of local government lies in the fact that it is focused on local development. Owing to this, local authorities have their own income at their disposal and can also access extraordinary sources of financial power, such as loans and credits. This duality government functioning can be the cause of its numerous real and financial problems, especially when the repartition of public funds between the central authority and local government is made incorrectly. The article focuses on the problems related to the issues of the influence of revenue sources on the financial independence and investment activity of municipalities in Poland.

Keywords: local government units (LGUs), financial independence, revenue sources, operating surplus, investment activity, Poland.

Streszczenie: Samorząd lokalny to część sektora finansów publicznych, dlatego znaczna część jego dochodów ma ściśle określony cel. Takie ukierunkowanie dochodów na finansowanie poszczególnych zadań ogranicza zakres autonomii finansowej samorządu terytorialnego i sprowadza ją do roli administrowania środkami publicznymi i wydawania ich na finansowanie poszczególnych zadań. Nadzór i kontrola nad jednostkami samorządu terytorialnego to także ograniczenie samodzielności finansowej jednostek samorządu 
terytorialnego (JST) - gmin, powiatów i województw. Jednocześnie istota samorządu terytorialnego polega na tym, że jest on skoncentrowany na rozwoju lokalnym. Dzięki temu władze lokalne mają do dyspozycji własne dochody oraz mają dostęp do nadzwyczajnych źródeł finansowania, takich jak pożyczki i kredyty. Ta dwoistość może być przyczyną jego licznych problemów realnych i finansowych, zwłaszcza w przypadku nieprawidłowego podziału środków publicznych między władzę centralną a samorząd terytorialny. Artykuł koncentruje się na problemach związanych z wpływem źródeł dochodów na samodzielność finansową i działalność inwestycyjną gmin w Polsce.

Słowa kluczowe: jednostki samorządu terytorialnego (JST), samodzielność finansowa, źródła dochodów, nadwyżka operacyjna, działalność inwestycyjna, Polska.

\section{Introduction}

An important feature of local self-government, which makes it different from other public authorities, is the independence of its organs from the state administration system. The empowerment of local communities that takes place in all democratic states has been achieved by giving local self-government the guarantee of independence, including financial independence. However, the financial independence of local self-government cannot be perceived in the same way as the financial independence of an entity that generates its own income. The financial authority of local self-government, both on the income and expenditure side, being an attribute of its financial independence, is limited to having financial resources derived from the "trimming" of primary income intended for public purposes. Therefore, the basic feature of the LGU financing system, more important than financial independence, is the adequacy of its income to the scope of the tasks performed.

The system of financing LGUs regarding the implementation of basic current tasks should be resistant to cyclical fluctuations. This is due to the fact that their own and obligatory tasks, just like statutory tasks, must be performed (provided) as long as they are ordered by the provisions of the applicable laws, regardless of the income held by LGUs. On the other hand, the essence of local self-government results in the independence of local authorities to decide on the directions of development, which is associated with having financial independence. The presented article focuses on some problems related to issues of the influence of revenue sources on the financial independence and investment activity of municipalities in Poland.

\section{The essence and scope of financial independence of local self-government}

Local self-government is part of the public sector, therefore its primary task is to meet the public needs by providing services. LGUs may perform these tasks only if they are equipped with the appropriate sources of financing. 
Local self-government, while performing tasks, has guaranteed independence and in this respect is subject to judicial protection. An important element of LGU independence is financial independence.

The concept of financial independence consists of revenue independence, namely the right of local self-government units to own and shape their own income as well as expenditure independence, i.e. independence in the scope of implementing their own tasks (Albaladejo \& Lopez, 2005).

In the opinion of the direct implementers of the budget economy, income-related independence is more important than expenditure and therefore it is often identified with independence in general (Piotrowska-Marczak, 1997).

The notion of the revenue independence of LGUs should be understood as the right of self-government authorities not only to have access to financial resources, but also to determine and acquire them. However, this right is not unconditional for at least two reasons.

Firstly, because in the economic sense, local self-government means the decentralization of tasks and financial resources by the state for public-legal unions, admittedly hierarchically not subordinate to the state but created by the will of the state. Therefore, since these unions are independent but not autonomous (they cannot exist without the state, they are subject to state jurisdiction, etc.), the competences of self-government authorities are depleted in the field of income-related activities. Local self-government authorities have limitations in the scope of shaping, for example, upper tax rates, they must accept statutory reliefs, they cannot freely shape payments for services, etc.

Secondly, revenue independence is also limited by the fact that local selfgovernment cannot unlimitedly maximize its income. If it has an excess in relation to the scope of tasks carried out, it is forced to redistribute them. An example of this is the balancing subsidy in Poland, or compensatory subsidies that make the income dependent on the tax potential, the scope of tasks performed, etc.

The above two restrictions define the financial autonomy framework of local self-government authorities. They also mean that revenue independence cannot be considered in isolation from the tasks performed by LGUs. When considering the obligatory nature of the majority of tasks implemented by local self-government and their usefulness (e.g. educational services or social assistance services), relying on stable sources of income, although determined by the central authorities may be a much better solution than granting one's own (but dependent on e.g. the economic situation) income.

Despite the aforementioned limitations to the disposal of income by the LGU authorities, one can however, speak of their revenue independence in the scope of deciding about spending the funds granted to them at their disposal (Bolivar, Galera, Muñoz, \& Subirés, 2016). 
Therefore when analysing the scope of revenue independence of LGUs, two important elements should be considered, i.e.:

- reliability and efficiency of individual sources of income,

- influence of self-government authorities on their formation.

Taking this into account, two opposite models of financing local self-government units can be distinguished:

- local government budgets based mainly on income from property and tax revenues, which is associated with a particular tax authority, giving the local self-government a considerable independence,

- local government budgets fed primarily with subsidies from the central budget, which may be the reason for the dependence of local authorities on government administration.

The first solution is more advantageous for the self-government authority because it allows (through reliefs, exemptions, change of tax scale and rates) to affect economic entities located in a given area.

Basing the financial system of LGUs - to a large extent - on own income also raises a number of dangers. Self-government authorities must be resistant to the pressure of residents and entrepreneurs striving to lower public levies, and it is also important that the level of budget income will be strongly dependent on the economic situation (Surówka, 2013).

In turn, the second solution is safer for self-government authorities because they can always count on the inflow of "due" income from the central budget. However in the case of the dominance of target subsidies, this may mean the dependence of local self-government on the government administration, which will control LGUs not only from the point of view of legality, but also the rationality and purposefulness of the funds spent. This model is characterized by the limited range of revenue independence of LGUs.

In the operations of local self-government in individual countries, there are mixed systems of financial power. In general, local self-government units everywhere have the scope of freedom in shaping their own income, including, in particular, the principles of constructing local public levies (Guillamon, Benito, \& Bastida, 2011).

The range of expenditure independence of LGUs is determined both by the level of income of these units and their structure. It seems that it is impossible to refer to the expenditure independence of LGUs without going into the scope of revenue independence. The independence of expenditure (distribution) of funds that are at the discretion of local self-government can be brought to their independence regarding (Kosek-Wojnar \& Surówka, 2002):

- determining priorities in the directions of expenditure of funds,

- shaping the economic structure of expenditure,

- managing the property taken over,

- shaping the budget balance,

- taking communal loans. 
To sum up, LGU expenditure independence is determined by:

- the type of tasks performed by these units; the higher the level of tasks of an obligatory nature, the lower the expenditure independence,

- the scope of legal regulations concerning the manner of performing public tasks under their responsibility,

- the range of fixed expenditure, and which therefore must be financed from the LGU budget,

- the level of own income and balancing income enabling the financing of tasks.

\section{Revenue independence and the adequacy of local self-government income to its tasks}

The previous considerations point out that analysing the notion of financial independence of LGUs raises a number of doubts. Questions arise as to: whether the revenue independence of LGUs can be considered in isolation from the scope of the tasks carried out, whether LGUs actually have expenditure independence, since a significant part of the tasks they perform is compulsory (in particular, obligatory own tasks and tasks commissioned by law), whether the standard of services of basic importance (e.g. in the field of education, social assistance) differs significantly in individual LGUs, and what will happen in the case of the abuse of revenue independence by local self-government authorities (e.g. through excessive use of tax reliefs and exemptions). The above questions can be asked much more often. The answer to them leads to the hypothesis that the basic feature of the LGUs financing system, more important than revenue independence (which in the public sector is in its nature limited), should be the adequacy (constancy) of LGUs income, i.e. adjusting funds to the scope of tasks (Wierzbicki, 2008).

The system of financing LGUs in implementing basic current tasks, especially obligatory ones, should be more resistant to cyclical fluctuations than in the case of performing other tasks (Wollmann, 2016). This is due to the fact that their own and obligatory tasks, just like statutory tasks, must be performed (provided) as long as they are required by statutory provisions, regardless of having sufficient income by LGUs. In addition - as mentioned earlier - the scope of LGUs independence in the field of obtaining own income is limited by the scope of the tax authority, and the horizontal redistribution exceeding the limits of own income in the case of financially strong LGUs, etc.

On the other hand, financial independence is limited by the legal limits of local self-government debt and the various rigours aimed at securing LGUs against the possibility of bankruptcy.

Taking into account the above limitations, it seems that the financial independence of local self-government (both income and expenditure), in terms of the implementation of obligatory tasks is of secondary importance in relation to the adequacy principle understood above. Therefore it cannot be compared to the independence of private sector entities. 
For the implementation of obligatory tasks (both own and commissioned), financial resources should be guaranteed to local self government by law. If the laws "impose" a range of tasks on the LGUs authorities, funds for their implementation should be structured in such a way as to ensure that these tasks can be carried out. Transfers from the state budget seem to be the most reliable source of financing in this respect.

Improvement of the LGUs' supply system in the financing of obligatory tasks should consist in shaping such a mechanism for the construction of subventions and targeted subsidies, which would guarantee the proper financing of expenditure. This is not an easy task for two reasons:

Firstly, there is a need to define the necessary level of financing services (and therefore their standardization).

Secondly, these funds are planned in the state budget (both subvention and targeted subsidies) and the central authority also has its priorities regarding the financing of other tasks.

Own income, which is a symptom of financial independence (both income and expenditure) of LGUs should, along with reimbursable revenues, be a source of financing of other tasks of local self-government.

The financial autonomy of local self-government should manifest itself first and foremost in the area of the financing and implementation of current optional tasks as well as financing its LGU investment activity. This applies to tasks in the field of communal infrastructure and socio-cultural tasks of above-basic importance (optional tasks). Their importance in meeting the needs of local communities is extremely significant. In this respect, the level of services provided is determined not so much by law but by the own financial capabilities of the local government unit, including the servicing of loans taken.

A manifestation of the financial independence of self-government authorities is also the tax authority of LGUs (Wollmann, 2012). It seems that more emphasis can be placed on the tax stimulus function than on their fiscal function when they will not be the basic source of financial support for local self-government, otherwise the stimulus function could significantly limit the implementation of the allocation function.

Summing up, it can be stated that due to the fact that local self-government is an entity of the public finance sector responsible for the implementation of a specific part of public tasks, when assessing financial independence the availability of efficient and reliable financial resources is first and foremost. Financial independence in the scope of shaping income and expenditure, including in particular tax authorities, is important because they make up the essence of local self-government, but are of secondary importance. Therefore, without denying the achievements of local selfgovernment institutions in the political and sociological levels, it should be noted that in legal and economic terms this independence is significantly limited by its public character. 
The doctrinal problem that needs to be resolved from the point of view of LGUs' financial autonomy is the answer to the question; what should be the proportion of obligatory and optional tasks implemented by LGUs in order to be able to talk about the relative financial independence of this public sub-sector?

\section{Financial independence of local self-government in the European Charter of Local Self-government}

The legal act defining the idea of local self-government is the European Charter of Local Self-government drawn up in 1985 in Strasbourg. It was ratified by Poland on April 26, 1993 (Act of 27.08.2009..., 1994). According to this legal act, local selfgovernment means the right and the ability of local communities, within the limits set by law, to direct and manage a fundamental part of public affairs on their own responsibility and in the interests of their residents. The right to manage public affairs should be exercised through the selection in free, secret, direct and general elections of the constituting bodies, which in turn can appoint their executive organs. An important statement of the ECLSG is the provision that: "responsibility for public affairs should be borne by those authorities that are closest to the citizens." This provision refers fully to the idea of subsidiarity. The Charter also emphasizes that local authorities have full freedom of action in any case that is not excluded from their competence or falls under the competence of other authorities. Questioning or limiting by another authority (central or regional) of these powers can only take place to the extent provided by law, in the manner and in cases specified by the Constitution or statutes.

The European Charter of Local Self-Government also applies to the principles of financing the tasks carried out. According to its provisions, the amount of financial resources of local communities should be adjusted to the scope of rights and at least some of these resources should come from specific local fees and taxes. The charter also includes the application of compensatory procedures or balancing measures aimed at correcting the effects of an uneven distribution of potential sources of income as well as expenditure incurred by individual LGUs. The ECLSG provision is also significant, assuming that the financial systems on which the resources available to local communities are based should be sufficiently diversified and flexible so that they can, as far as possible, correspond to the real changes occurring in the level of costs related to the exercise of rights. This provision is extremely important because it guarantees local self government access to financial resources even if, as a result of an economic downturn, their own income is limited. In turn, in order to enable LGUs to finance investment projects, the ECLSG guarantees them access to the domestic capital market.

The European Charter of Local Self-Government reflects the essence of local self-government, becoming the basis for the functioning of local self-government in 
modern countries and securing the interests of local communities in relation to government administration. It is also a guarantee of ensuring two principles, i.e. decentralization and subsidiarity, on which modern local self-government is based.

This approach to local self-government is in line with the concept of localization, which is included in the view that the fundamental feature of self-government is the diffusion of power (King, 1995). Thanks to local self-government there is the fragmentation of power, which becomes more accessible and more flexible, and by getting closer to the public it can also make more rational decisions.

\section{Sources of income and financial independence of local self-government in Poland}

The range of revenue independence of LGUs varies depending on the type of budget income (Vanags \& Vilka, 2006). It is the largest in the case of local taxes and fees and income from property, and much smaller for percentage shares in central taxes, general subventions and targeted subsidies.

An important source of income for local self government is income from taxes and fees. In classifying the taxes that feed the budgets of local self-government they can be divided into (Kosek-Wojnar \& Surówka, 2002):

- autonomous taxes, introduced independently by local authorities,

- local taxes and fees set by law, but entirely provided to the local self-government,

The receipts from the self-taxation of residents are an example of the most farreaching autonomy of local self-government in shaping their own sources of income. Local authorities, on the basis of their own local legislation, decide to charge natural or legal persons with additional public levies, adopting appropriate resolutions in this regard. They are also responsible for determining the individual elements of taxation techniques in their resolutions.

Due to the fact that these competences are generally reserved for the state legislature, in most countries where autonomous taxes operate, their introduction in a given area is voiced by all residents through a referendum. They are introduced rather exceptionally to carry out a project of significant importance most often concerning the collection of funds for financing investment expenditure.

The basic source of tax income, especially local budgets, is local taxes and fees. They differ from autonomous taxes in that they are introduced by law, in a uniform manner throughout the whole country, and not through resolutions of the local selfgovernment bodies. Due to the fact that they have been handed over as a source of income to local self-government, local authorities receive from the legislator specific power of taxation. This consists in the fact that these authorities determine the amount of tax rates, the amount of fees, they can apply reliefs and exemptions, and can also write off receivables, and distribute them into instalments, etc. Maximum rates, however, are set by law in a uniform manner at country level. 
However there is some danger associated with local tax authorities, consisting in the possibility of reducing budget inflows by lowering tax rates by local authorities (significantly below maximum rates), applying in a wide range of reliefs, tax remissions and even numerous objective and subjective exemptions. Local selfgovernment has also problems generally larger than those of the central tax authorities, with the effectiveness of tax enforcement. All this is caused by pressure from local residents of communes, which local authorities are exposed to. These authorities are closer to taxpayers, thus less anonymous, and also chosen by them. As a result they are less resistant to various pressures from local communities. This means that the local community as a whole loses out on it, because it deprives them of some of the income that could be obtained by applying maximum rates or abandoning reliefs, deferrals and remissions.

In Poland, communes have the proceeds from property tax, agricultural tax, forestry tax, transport tax, civil law transactions tax, inheritance and donations tax, and lump-sum income tax paid in the form of a tax card. In addition, their income includes proceeds from public and legal fees such as local, spa, market, dog, exploitation, adjacent, etc. This is income from typical local taxes and fees, which in no other country are among efficient sources of income. On the other hand, they are not only a source of income, but also tools through which (by the application of reliefs, exemptions for tax deferrals) local government authorities have the opportunity to influence entities located in their area. For this reason, their rank in the income system is high.

The low efficiency of local taxes means that local self government also have access to central taxes from a given area. It should be emphasized that the income from these taxes is an important source of financial power, enabling local self government to perform basic tasks. In many cases, revenue from state taxes exceeds income from local taxes.

The budgets of individual levels of local self-government are generally not supplied with all central taxes. They rarely have access to indirect taxes, only participating in the distribution of income taxes. This is justified by the fact that local authorities do not have a major impact on the development of income, e.g. from excise taxes. The level of this tax income depends primarily on the volume of sales in the given area of monopoly and luxury products. The introduction of this source of income into the LGU budgets would encourage the localization of refineries, tobacco plants and spirits companies in each commune or region, which is not always intentional and rational. Therefore most often the financial supply of local and regional budgets is limited to transferring part of income tax receipts to selfgovernment authorities.

The volume of income tax receipts both from natural and legal persons is a symptom of the economic development of a given area. LGUs should participate in the division of the national income generated in a given area, also in the part which 
is subject to redistribution to the central budget. However the question arises as to what form this redistribution of funds should take.

In practice, local self-government participate in the division of central taxes, either through the establishment of local self-government allowances to income taxes, or through percentage contributions to income taxes. The significance of both forms is varied.

The main difference between the tax share and the tax allowance is that in the case of the former, local authorities do not have a greater impact on the size of budget income. The funds due to self-government authorities are calculated automatically. The legislator decides on the amount of the share. Depending on the amount of tax revenues obtained in a given area, local authorities receive a percentage of the income from these taxes. However, this income does not have motivational functions because:

- they do not require more effort from local authorities to obtain them,

- local self-government authorities can not actively influence entities located in their area through them,

- they have no significant potential to affect their growth.

All this means that the share in taxes is treated as supplementary and not own sources of financial power for local self-government (Denek, 2011), they resemble general subsidies in their character. Differences between general subsidies and shares in central taxes basically consist in that general subsidies are used to balance the budgets of financially weaker local communities, while shares in central taxes dominate as a source of budget income of local self-government with significant economic potential.

Tax allowances differ essentially in their economic nature from shares in taxes. The introduction of a local allowance to the state tax means that the local authorities have the statutory authority to impose a fiscal burden. The allowance flows into the local self-government budget and functions alongside the tax rates that determine the level of central budget income. The maximum amount of the allowance can be determined by the central authorities. However, local self-government authorities determine the amount of the allowance below the maximum, diversifying it in individual periods, less frequently in relation to specific entities, but within its tax authority. The right to set allowances to state taxes means that local authorities have tools through which they can actively influence entities that create the economic base of a given area. Therefore, while the tax share has only fiscal significance, the allowance, in addition to the fiscal function, may also have a significant stimulating effect in certain conditions, influencing the behaviour of entities operating in a given area. Given that income taxes are a fairly efficient source of public income, by establishing allowances to state taxes, local self-government achieve a double benefit, i.e. access to an efficient source of income, and also in addition to using it (by 
setting the size of the allowance), they can stimulate the development of entrepreneurship on their own area (Kosek-Wojnar \& Surówka, 2002).

Local self-government is the owner of the majority of public property in its area. These are buildings, land, as well as economic entities whose founding body is, or in which, the LGU authorities have their share. This property brings to local selfgovernment units various income in the form of rental fees, dividends, surplus payments of budgetary establishments, income for services rendered, fees for using municipal infrastructure and income from the sale of property (Patrzałek, 2010).

Income from property is a heterogeneous source of income for local selfgovernment budgets. The dominant role in this group accounts for services fees provided by local self-government units. These include fees for services such as garbage collection, sewage disposal, street cleaning, road maintenance, water supply for residents, heat and electricity, fees for kindergartens, swimming pools, admission to museums, etc. Most often, receipts from services provided do not cover the expenses incurred for this purpose. However it should be emphasized that the local self-government should, in principle, make the property available to the local community not to get rich (to earn profits), but to provide the residents with the right living conditions.

A source of income from local property may also be the sale or lease of particular parts of property, in particular land, municipal buildings, technical infrastructure, etc. (Poniatowicz, 2011).

In principle, in all countries, local self-government as part of its public tasks also conducts economic activity. Then the source of budget income may be revenue from income generated by this activity. The scope of the conducted economic activity by local self-government units raises, however, numerous doubts and disputes. This applies in particular to profit-oriented economic activity. Among other things, historical considerations support carrying out this type of activity. In the initial period of local self-government functioning there were no legal obstacles to conducting economic activity by communes (Gogolewska, 1994).

In turn, the following arguments are put forward against commercial activities carried out by local self-government (Wasilewski, 1991):

- the basic task of local government is to carry out public tasks, and not to conduct a commercial activity,

- the freedom to conduct a constitutionally guaranteed economic activity in a state of law should not apply to entities of a public authority,

- every economic activity may also bring losses, and this will be a threat to satisfying the obligatory tasks of local self-government units,

- the involvement of local authorities in direct economic activity may lead to the violation of the rules of economic freedom and economic competition.

The arguments mentioned above mean that the practice in this matter varies in each country (Najniger, 1998). In general, however, extreme solutions are avoided. 
That is why self-government authorities in European countries favour the development of entrepreneurship, yet they sometimes intervene directly in order to activate private capital, for example by creating enterprises, preparing areas and facilities to conduct economic activity, but without directly engaging in production activities.

The basic source of budget income for the majority of LGUs, both in Poland and in other countries, is subsidies and compensatory subventions. The necessity of an external power supply is indispensable because income from taxes and property of self-government communities in any country is not sufficient to finance budget expenditures.

Transfers from the state budget are a form of compensating for "lost" income from a given area for local self-government caused by the fact that the most efficient taxes supply the central budget. Income from subsidies, in contrast to taxes, does not, however, have motivational functions: local government authorities can not actively influence entities located in their territory through them. They also have no more opportunity to increase them.

Subsidies and subventions are intended to counteract development disparities of individual local self-government units. The correct mechanism of their calculation does not necessarily limit the rules of self-government and for this to happen, two basic conditions should be met:

- firstly, compensatory measures should be set based on objectified criteria and local self-government should know what revenues they have,

- secondly, local self government should independently decide on the allocation of funds received.

The above-mentioned conditions are met by general subsidies (subventions). The long history of local self-government in the West shows that the criteria on the basis of which general subsidies for local self-government are transferred are sometimes considerably expanded. The amount of funds allocated may depend on many factors. Most often it is the number of residents, the age structure of the population, the value of municipal infrastructure devices located in the commune, 'powiat' and region, tax potential, etc.

The second form, in addition to general subsidies, of LGU external financial supply is targeted subsidies. Funds from this account are granted to local selfgovernment for financing specific projects, most often for the implementation of commissioned tasks, as well as for financing investments. However, targeted subsidies as a source of LGU income are generally criticized. They cause dependence of the local government receiving subsidies on the government administration and on other LGUs. They are transmitted for a specific purpose, they must be settled and the unused part should be returned to the subsidizing entity. The disadvantage is also the fact that the amount of funds allocated is always decided by the transferor, guided by their own calculations which may not always be beneficial for the recipient. 


\section{The revenue structure of communes in Poland in the period 2011-2018 and its impact on the size of operating surpluses and investment activity}

Tables 1-2 present the structure of income of communes and cities with 'powiat' rights in 2011-2018. These quantities were presented in zlotys and not in percentages to show the phenomena occurring in this period and overlapping phenomena.

Table 1. The revenue structure of communes in 2011-2018 (in PLN billion)

\begin{tabular}{|l|c|c|c|c|c|c|c|c|}
\hline \multicolumn{1}{|c|}{ Type of income } & 2011 & 2012 & 2013 & 2014 & 2015 & 2016 & 2017 & 2018 \\
\hline Total income & 75.8 & 78.4 & 80.0 & 84.5 & 87.7 & 101.8 & 111.2 & 121.1 \\
\hline Own income & 22.2 & 23.7 & 25.0 & 27.0 & 27.5 & 30.0 & 31.0 & 30.7 \\
\hline PIT and CIT & 12.4 & 12.8 & 13.6 & 14.7 & 16.1 & 17.4 & 19.2 & 21.6 \\
\hline Subvention & 23.3 & 24.6 & 24.8 & 24.6 & 25.4 & 26.4 & 27.0 & 28.3 \\
\hline Targeted subsidies & 17.9 & 17.3 & 16.6 & 18.2 & 18.7 & 28.0 & 34.0 & 40.5 \\
\hline
\end{tabular}

Source: own elaboration based on data from the Ministry of Finance, values in current prices.

Table 2. Structure of income of cities with 'powiat' rights in 2011-2018( in PLN billion)

\begin{tabular}{|l|l|l|l|l|l|l|l|l|}
\hline \multicolumn{1}{|c|}{ Type of income } & 2011 & 2012 & 2013 & 2014 & 2015 & 2016 & 2017 & 2018 \\
\hline Total income & 56.9 & 61.2 & 64.2 & 68.3 & 70.6 & 74.4 & 78.7 & 85.5 \\
\hline Own income & 20.4 & 21.5 & 23.8 & 25.2 & 25.8 & 26.3 & 28.1 & 27.3 \\
\hline PIT and CIT & 15.6 & 15.9 & 16.3 & 17.7 & 19.0 & 20.2 & 20.3 & 25.0 \\
\hline Subvention & 12.5 & 13.3 & 13.5 & 13.6 & 13.9 & 14.3 & 14.8 & 15.4 \\
\hline Targeted subsidies & 8.4 & 10.5 & 10.6 & 11.8 & 11.9 & 13.6 & 15.5 & 17.8 \\
\hline
\end{tabular}

Source: own elaboration based on data from the Ministry of Finance, values in current prices.

In 2011-2018 the share of own income increased (together with PIT and CIT) in the structure of the total income of both communes and cities with 'powiat' rights. In the case of communes, within eight years own income (together with shares in PIT and CIT) increased by almost PLN 16 billion, and for cities with 'powiat' rights by more than PLN 12 billion. The growth dynamics of this group of income amounted respectively, in the case of communes to $51 \%$ and for cities with 'powiat' rights - to over $45 \%$. Such a large increase in LGUs own income was caused by the good economic situation in Poland reflected in the increase in local taxes and income taxes.

Despite the dynamic growth of own income of communes and cities with 'powiat' rights, its share in the total income structure has practically not changed, and even slightly deteriorated. This was due to the increase in the share of targeted subsidies, for the implementation of expenditure on commissioned tasks, in particular for the payment of childcare benefits (the so-called 500+) related to the social policy of the 
central authorities, which won the election in 2015. As of 2016, expenditure for these services amounts to over PLN 30 billion annually (over 8\% of state budget expenditure) and is transferred to communes for implementation in the form of targeted subsidies as a delegated task. This meant that the share of targeted subsidies in the structure of income of communes and cities with 'powiat' rights increased by about $10 \%$. Had it not been for the dynamic increase in own income (due to the good economic situation in Poland after 2014), targeted subsidies would have dominated in the revenue structure of communes, undermining the essence of local selfgovernment. The use of targeted subsidies is controlled and supervised by external institutions, not only from the point of view of legality, but also the purposefulness, reliability and economy of spending funds.

The increase in targeted subsidies after 2016 was accompanied by a drop in operating surpluses. This is due to the fact that targeted subsidies for tasks commissioned in Poland do not cover $100 \%$ of the costs of carrying out the tasks ordered. Communes pay extra from their own income for the majority of commissioned tasks. This then limits the amount of operational surpluses and development opportunities of LGUs. The level of funds that can be spent on servicing the liabilities incurred is decreasing.

Tables 3-4 present the current income and current expenditure of communes and cities with 'powiat' rights in 2011-2018.

Table 3. Current income and current expenditure of communes in Poland in 2011-2018 (in PLN billion)

\begin{tabular}{|l|r|r|r|r|r|r|r|r|}
\hline \multicolumn{1}{|c|}{ Communes } & 2011 & 2012 & 2013 & 2014 & 2015 & 2016 & \multicolumn{1}{c|}{2017} & \multicolumn{1}{c|}{2018} \\
\hline Current income & 68.7 & 71.6 & 73.8 & 78.2 & 84.2 & 100.9 & 106.0 & 111.4 \\
\hline Current expenditure & 61.4 & 64.3 & 66.3 & 69.6 & 71.5 & 87.2 & 95.6 & 100.9 \\
\hline Operating surplus & 7.3 & 7.3 & 7.5 & 8.6 & 12.7 & 13.7 & 10.4 & 10.5 \\
\hline
\end{tabular}

Source: own elaboration based on data from the Ministry of Finance, values in current prices.

Table 4. Current income and current expenditure of cities with 'powiat' rights in Poland in 2011-2018 (in PLN billion)

\begin{tabular}{|l|r|r|r|r|r|r|r|r|}
\hline Cities with poviat rights & 2011 & 2012 & 2013 & 2014 & 2015 & 2016 & 2017 & 2018 \\
\hline Current income & 50.7 & 52.7 & 55.2 & 58.3 & 63.6 & 70.2 & 74.4 & 79.4 \\
\hline Current expenditure & 48.4 & 51.1 & 52.5 & 55.1 & 56.9 & 63.4 & 68.1 & 72.3 \\
\hline Operating surplus & 2.3 & 1.6 & 2.7 & 3.2 & 6.7 & 6.8 & 6.3 & 7.1 \\
\hline
\end{tabular}

Source: own elaboration based on data from the Ministry of Finance, values in current prices.

In 2014-2016, operating surpluses in communes and cities with 'powiat' rights clearly increased in relation to the previous years. This was caused by the economic recovery and the increase in income from local taxes and from contributions to income taxes, especially in PIT. 
Communes, in accordance with the Act on income of local self-government units, have the right to a $39.34 \%$ share in the tax in their area. The good economic situation meant that tax income, especially from PIT, increased and this had a positive impact on the level of operating surpluses. In 2014-2016, operating surpluses accounted for $12 \%$ of communal expenditure.

After 2016, we can observe a drop in operating surpluses in communes. In the case of cities with 'powiat' rights throughout the period 2015-2018, the relation of operating surpluses to current expenditure remains at a similar level.

LGUs' operational surpluses are an important source of financing investment activities. If the increase in investment expenditure is not accompanied by a proportional increase in operating surpluses, then there is an increase in the indebtedness of LGUs. Such a situation took place in Polish local self-government in 2007-2011.

The financial perspective of 2007-2013 (the first full one after the accession of Poland to the EU), created the possibility of obtaining "cheap" money for investments. At the same time, it was a difficult period for LGUs in terms of their financial situation. The economic slowdown, which (due to the method of calculating shares in PIT and CIT) reached LGUs with a two-year delay, meant that LGUs did not have operating surpluses on the so-called own contribution.

Within three years, income from PIT and CIT:

- in the case of communes, it decreased from 11.4 in 2008 to PLN 10.6 billion in 2009-2010,

- for cities with 'powiat' rights, it decreased from PLN 15.8 billion in 2008 to PLN 15.1 billion in 2009 and PLN 14.4 billion in 2010, and

- for counties ('powiat'), it decreased from PLN 3.1 billion in 2008 to PLN 2.8 billion in 2009-2010.

Other own income (mainly local taxes) were also low and transfers from the state budget (targeted subsidies and subventions did not secure 100\% of commissioned tasks and own tasks).

In order to reach for EU funds, LGUs started to get into debt.

Table 5 presents the amount of LGUs' liabilities in Poland in 2004-2011.

Table 5. Size of the liabilities of individual LGU groups in 2004-2011 (in PLN billion)

\begin{tabular}{|l|r|r|r|r|r|r|r|r|}
\hline \multicolumn{1}{|c|}{ Liabilities } & 2004 & 2005 & 2006 & 2007 & 2008 & 2009 & 2010 & 2011 \\
\hline LGU total & 19.2 & 21.2 & 25.0 & 25.9 & 28.7 & 40.2 & 58.0 & 65.8 \\
\hline Communes & 7.6 & 8.1 & 9.6 & 10.0 & 10.8 & 14.6 & 21.9 & 26.0 \\
\hline Cities with poviat rights & 9.5 & 10.4 & 11.3 & 11.3 & 12.8 & 18.7 & 23.4 & 28.1 \\
\hline
\end{tabular}

Source: Ministry of Finance data on the implementation of the budget by LGU for 2004-2011

It should be noted that in 2008-2011 the indebtedness of:

- communes increased from PLN 10.8 billion to PLN 26 billion,

- cities with 'powiat' rights increased from PLN 12.8 billion to PLN 28.1 billion. 
The financial burdens from the previous period, but also the new tasks imposed on LGUs after 2015, affect their current economic condition.

Table 6 presents expenditure on investments in communes and cities with 'powiat' rights in 2011-2018.

Table 6. Property expenditure as a percentage of total expenditure

\begin{tabular}{|l|c|c|c|c|c|c|c|c|}
\hline $\begin{array}{c}\text { Property expenditure } \\
\text { in \% }\end{array}$ & 2011 & 2012 & 2013 & 2014 & 2015 & 2016 & 2017 & 2018 \\
\hline LGU total & 23.4 & 19.7 & 19.0 & 21.0 & 19.6 & 12.5 & 15.3 & 20.4 \\
\hline Communes & 22.9 & 18.1 & 19.9 & 16.6 & 16.9 & 11.1 & 14.6 & 20.6 \\
\hline Cities with poviat rights & 21.2 & 19.9 & 19.1 & 20.9 & 18.5 & 12.0 & 14.1 & 16.9 \\
\hline
\end{tabular}

Source: Ministry of Finance data on the implementation of the budget by LGUs for 2011-2018.

After 2011, expenditure on investments began to decrease in all groups of LGUs. For example, in 2011 the share of investments in the total expenditure of communes was $23 \%$ and in 2016 it fell to $12.5 \%$. In the case of cities with 'powiat' status, the decrease was also large (from $21 \%$ in 2011 to $12 \%$ in 2016). This was a very unfavourable phenomenon, considering that another financial perspective was initiated within the framework of the European Union budget for 2014-2020, creating the possibility of obtaining financial resources by Poland. Local self-government in Poland is an important beneficiary of these funds, also due to the types of EU funds as well as the investment needs of communes.

From 2017, expenditure on investment in LGUs budgets started to increase again. In the case of communes, within two years, expenditure on investment increased by PLN 10 billion (from PLN 16.4 billion in 2016 to more than PLN 26 billion in 2018), and in the case of cities with 'powiat' rights, by PLN 7 billion (from PLN 8.5 billion in 2016 to nearly PLN 15 billion at the end of 2018). The significant increase in investment expenditure after 2017 should be assessed positively, mainly due to the still large needs of local self-government in the development of municipal and social infrastructure.

The increase in investment expenditure, however, contributes to the increase in debt, especially of communes and cities with 'powiat' rights. The cautious investment policy in the period 2014-2016 caused by a change of power at central and local levels (the election in 2015 to the Parliament and in 2018 to local authorities) meant that the liabilities of communes and cities with 'powiat' rights in 2014-2016 did not change. After the election, the situation in the field of undertaking investment activities began to stabilize. Therefore, after two years of the impeding investment activity, LGUs started investing again, which is clearly signalled by the increase in loans and thus the increase in liabilities. This is presented in Tables 7 and8.

Table 7 presents the liabilities of communes, cities with 'powiat' rights in 20112018 . 
Table 7. Liabilities of communes and cities with 'powiat' rights in 2011-2018 (in PLN billion)

\begin{tabular}{|l|c|c|c|c|c|c|c|c|}
\hline \multicolumn{1}{|c|}{ Liabilities } & 2011 & 2012 & 2013 & 2014 & 2015 & 2016 & 2017 & 2018 \\
\hline Communes & 26.0 & 26.2 & 25.8 & 26.4 & 25.4 & 23.9 & 24.8 & 30.1 \\
\hline Cities with poviat rights & 28.1 & 29.6 & 30.9 & 32.4 & 33.2 & 32.8 & 32.4 & 33.6 \\
\hline
\end{tabular}

Source: Ministry of Finance data on the implementation of the budget by LGUs.

In 2011-2016, the stabilization of the communal debt in Poland was visible. The liabilities of LGUs in Poland at the end of 2016 reached PLN 69 billion (in the period 2014-2016 they did not change).

However, the increase in investment expenditure after 2016 meant that at the end of 2018, LGUs liabilities increased to PLN 76 billion, whereas the debt of cities with 'powiat' rights amounted to PLN 33.6 billion (an increase in relation to the previous year of more than PLN 1 billion), and the communal debt during the year increased by over PLN 5 billion, exceeding at the end of 2018 PLN 30 billion.

Tables 8 and 9 present the credits and loans taken and repaid by communes and cities with 'powiat' rights in 2011-2018 (without free funds).

Table 8. Credits and loans taken by communes and their repayment in 2011-2018 (in PLN billion)

\begin{tabular}{|l|c|c|c|c|c|c|c|c|}
\hline \multicolumn{1}{|c|}{ Communes } & 2011 & 2012 & 2013 & 2014 & 2015 & 2016 & 2017 & 2018 \\
\hline Credits taken & 8.6 & 5.7 & 5.7 & 4.5 & 3.4 & 2.5 & 4.7 & 9.3 \\
\hline Repayment of credits & 4.7 & 5.4 & 5.9 & 3.7 & 4.3 & 3.9 & 3.7 & 4.0 \\
\hline
\end{tabular}

Source: Ministry of Finance data on the implementation of the budget by LGUs.

Table 9. Credits and loans taken by cities with 'powiat' rights and their repayment in 2011-2018 (in PLN billion)

\begin{tabular}{|l|c|c|c|c|c|c|c|c|}
\hline Cities with poviat rights & 2011 & 2012 & 2013 & 2014 & 2015 & 2016 & 2017 & 2018 \\
\hline Credits taken & 8.5 & 5.0 & 4.9 & 4.8 & 3.5 & 1.9 & 2.6 & 4.5 \\
\hline Repayment of credits & 3.4 & 3.3 & 3.9 & 3.2 & 2.6 & 2.6 & 3.0 & 3.1 \\
\hline
\end{tabular}

Source: Ministry of Finance data on the implementation of the budget by LGUs.

The figures contained in Tables 8 and9 show that in 2014-2016 communes and cities with 'powiat' rights conducted a very cautious investment policy, stabilizing their indebtedness. In the case of communes in 2015-2016, and cities with 'powiat' rights in 2016-2017, the repayment of loans and redemption of securities were higher than credits taken. In 2018 there was a significant increase in credits and loans taken, which in turn led to an increase in debt of LGUs. It seems that this is a beneficial phenomenon, because it is difficult to carry out public tasks without incurring investment expenditure. Negligence in the level of social and technical infrastructure 
is still high. The question arises as to how long individual debt repayment indicators (defined in the Public Finance Act) will allow LGUs to pursue an investment policy related to the use of EU funds.

\section{Conclusion}

The integrity of local self-government finances with the entire public finance system limits its financial independence, despite the political and legal independence of local self-government authorities from the central administration.

The sources of local self-government income should be primarily adapted to the scope of tasks performed. On the other hand, self-government authorities should have influence on running their own policy and deciding on directions of development. In this case, the guarantee is own income and, in particular, the ability to run their own tax policy. However, this carries certain risks, especially in the event of an economic downturn. Therefore, own income should not dominate in the structure of local self-government income.

In Poland, local self-government at the level of communes ('powiat') to a large extent deals with "administering" and not deciding on the directions of its development. This makes tasks financed with targeted subsidies and educational subvention account for over $65 \%$ of total expenditure.

The financial condition of local self-government in Poland after 2011 is generally good. Communes do not have major problems with financing current operations. They also have operating surpluses that allow them to finance their investments. The problem is that operating surpluses to a large extent result not only from good economic conditions, but also from the "investment stagnation" that occurred after 2012. Excessive debt from 2007-2011 forced, by exceeding debt ratios, limiting the investment activity of communes. This was particularly evident in 2015-2016, despite the improvement of communes' finances and their increasing own income.

The increase in investment expenditure of communes after 2016 meant that within two years their indebtedness increased by about $10 \%$. This will probably lead to a reduction in investment in subsequent years as a result of exceeding individual indebtedness indicators.

It is possible to counteract this unfavourable situation by planning in the state budget, subsidies for financing the development activities of communes. They would be an own contribution enabling to access EU funds in the 2020-2026 perspective. Otherwise, during an economic recession, communes (especially big cities) will have serious problems with maintaining and developing social and technical infrastructure, which will then reduce the quality of services provided. 


\section{Bibliography}

Albaladejo F. J. B., \& Lopez B. B. (2005). Analysis of local governments indebtedness: An empirical study. Revista Espanola de Financiacion y Contabilidad, 34(126), 613-635.

Act of 27.08.2009 on Public Finances (consolidated text: OJ of 2013 item 885 as amended).

Bolivar, M. P. R., Galera, A. N., Muñoz, L. A., \& Subirés M. D. L. (2016). Risk factors and drivers of financial sustainability in local government: An empirical study. Local Government Studies, 42(1), 29-51.

Denek E. (2011). Ryzyko w gromadzeniu dochodów przez samorząd powiatowy w świetle jego zadań (wybrane problemy). In Patrzałek, L. (Ed.). Finanse - nowe wyzwania teorii i praktyki. Finanse publiczne. Wrocław: Wydawnictwo Uniwersytetu Ekonomicznego we Wrocławiu.

European Charter of Local Self-Government Card, Journal of Laws of 1994 no. 134, item 607.

Gogolewska, J. (1994). Ekonomiczne oddziaływania samorządu terytorialnego. In Winiarski, B., \& Patrzałek, L. (Eds.). Promowanie rozwoju lokalnego i regionalnego. Warszawa: Fundacja Rozwoju Lokalnego.

Guillamon D. M., Benito B., \& Bastida F. (2011). Evaluation of local government debt in Spain. Revista Espanola de Financiacion y Contabilidad, 40(150), 251-285.

King, D. (1995). From the Urban left to the New right. Normative theory of Local government. In Seward, J., \& Stocker, G. (Eds.). Local government in the 1990s. New York: MacMillan.

Kosek-Wojnar, M., \& Surówka, K. (2002). Finanse samorządu terytorialnego. Kraków: Wydawnictwo Akademii Ekonomicznej w Krakowie.

Najnigier, S. (1998). Rola samorządu terytorialnego w rozwoju gospodarki lokalnej. Finanse Komunal$n e, 3$.

Patrzałek, L. (2010). Finanse samorządu terytorialnego. Wrocław: Wydawnictwo Uniwersytetu Ekonomicznego we Wrocławiu.

Piotrowska-Marczak, K. (1997). Finanse lokalne w Polsce. Warszawa: Wydawnictwo Naukowe PWN.

Poniatowicz, M. (2011). Nieruchomość jako źródło dochodów własnych gminy z uwzględnieniem możliwości oddziaływania władz samorządowych na ich wielkość. In L. Patrzałek (Ed.), Finanse - nowe wyzwania teorii i praktyki. Finanse publiczne. Wrocław: Wydawnictwo Uniwersytetu Ekonomicznego we Wrocławiu.

Surówka, K. (2013). Samodzielność finansowa samorzadu terytorialnego w Polsce: teoria i praktyka. Warszawa: Polskie Wydawnictwo Ekonomiczne.

Vanags, E., \& Vilka, I. (2006). Local government in the Baltic states: Similar but different. Local Government Studies, 32(5), 623-637.

Wasilewski, A. (1991). Działalność gospodarcza a funkcje i zadania gmin. Samorząd Terytorialny, 11-12.

Wierzbicki, J. (2008). W stużbie nauki o finansach: Klasycy nauki poznańskiej. Poznań.

Wollmann, H. (2012). Local government reforms in seven European countries: Between convergent and divergent, conflicting and complementary developments. Local Government Studies, 38(1), 41-70.

Wollmann, H. (2016). Local government reforms: Between multifunction and single-purpose organizations. Local Government Studies, 42(3), 376-384. 